\title{
Growth, carcass traits and meat quality of Bronze and White turkeys in Isparta province of Turkey
}

\begin{abstract}
Summary
In this study; the growth, carcass traits and meat quality were determined in Bronze and White turkeys, in comparison one another in Isparta province of Turkey.

Average of body weights of bronze and white turkeys were 7495-4843g and 15844-11797g; average percentages of carcass were $74.0-71.2 \%$ and $82.7-81.9 \%$; average percentages of crude protein content of muscle meat of breast, legs were $23.0-26.1 \%, 19.0-21.2 \%$ and $16.5-17.4 \%, 13.3-14.8 \%$ at the age of 18 -weeks, respectively.

Significant differences were determined $(\mathrm{P}<0.05)$ between genotypes of body weights, carcass traits, meat qualities, and also between males and females of genotypes.
\end{abstract}

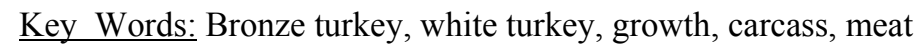

\section{Zusammenfassung}

Titel der Arbeit: Wachstum, Schlachtkörpermerkmale und Fleischqualität von bronzefarbenen und weißen Puten in der Isparta-Provinz der Türkei

In dieser Untersuchung wurden Wachstum, Schlachtkörper- und Fleischqualität von bronzefarbenen und weißen Puten ermittelt und verglichen. Das durchschnittliche Körpergewicht im Alter von 18 Wochen der männlichen und weiblichen bronzefarbenen Puten erreichte 7495 und 4843 g, das der männlichen und weiblichen weißen Puten 15844 und 11797 g. Die Schlachtausbeute lag bei 74,0 und 71,2 \% bei den bronzefarbenen Puten und bei 82,7 und 81,9 \% bei den weißen Puten. Der Rohproteingehalt des Muskelfleisches der Brust betrug 23,0 und 26,1 \% sowie 19,0 und 21,2 \%, der des Muskelfleisches der Schenkel 16,5 und 17,4 \% sowie 13,3 und 14,8\%. Die Differenzen zwischen den Genotypen und den Geschlechtern waren signifikant verschieden $(\mathrm{P}<0,05)$.

Schlüsselwörter: Bronzefarbene Puten, weiße Puten, Wachstum, Schlachtkörper, Fleisch

\section{Introduction}

The recorded history of the turkey spans about 500 years, turkeys originated in North America, were domesticated in Europe, and are now an important source of food in many parts of the world (BRANT, 1998), and it was suggested that turkey red meat will be alternative to cattle meat in the future (NIXEY, 1986).

Turkey has approximately three millions of turkey population and the most of turkeys are American Bronze turkeys. On the other hand, turkey production were limited due to the seasonal raising in Turkey. Because turkey meat consumption were dependent to new year's day. In this way, turkey meat production were not increasing and developing. Furthermore, there were not the processing units of turkey meat (TURKOGLU et al., 1990, 1991). However, turkey growing and marketing developed during 4-5 years late in Turkey and turkey meat production were tried to increase by the new turkey hybrids. Generally, Bronze turkeys were raised by rural areas and a widespread genotype. At sun rising Bronze turkeys went out from the hen house to the pastures, to the harvested fields and they come back to hen house in the evening. From 
June until November Bronze turkeys have been fed by the remaining of corn mix after harvest. They were raised in extensive conditions (ISGUZAR and TESTIK, 2001). In the late time, the turkey meat demand increased, and consequently, white turkeys have begun to be raised in intensive conditions in Turkey. Because white turkeys have been rapidly growing in short time compared to Bronze turkeys.

For this reason, the purpose of this research was to investigate growth, carcass traits and the nutrient content of meat of Bronze and White turkeys growing up in intensive conditions, and to find out differences between Bronze and White Turkey genotypes.

\section{Material and method}

The experiment was conducted with day old chicks of Bronze and White genotypes in the hen house. Each of the genotype group was consisted of 50-80 chicks, and all groups were identified with attaching metal wing numbers without sexing and were weighted by electronic weight tool $( \pm 2 \mathrm{~g})$ at the age of $0,1,3,5,7,9,11,14,18$ weeks.

The birds were only fed commercial broiler starter ration (granule of $22 \%$ protein and $3060 \mathrm{kcal} / \mathrm{kgME}$ ) for the first 4-weeks and broiler grower diet (pellets of $21 \%$ protein and $3200 \mathrm{kcal} / \mathrm{kgME}$ ) between 5 and 18 weeks of age. The turkey poults had have ad libitum feed and no grazing, no meadow, etc. Feed consume of genotypes were weekly determined. They were kept under intensive conditions and in hen house there were hay litter on the ground and automatic plastic feeder and waterier. Furthermore, poults were placed equal numbers on one meter square in pens in hen house.

All living turkeys were slaughtered at 14 and 18 weeks of age and were cut to determine the part of the carcasses. The carcasses and their parts were weighted without viscera and with skins.

Three birds of each sex and each group were taken to analyse the chemical meat composition at 14 and 18 weeks of age. The results of body composition and protein, fat analyses were shown for the races Bronze and White turkeys. Crude protein and fat analyses of muscular meat were made by Kjeldahl and Soxhlet tool, respectively (JAMES, 1995; ANON, 1993). Bio-statistical analyses were done with MINITAB for WINDOWS (version 10.5) and MstatC programme was used for the test of significance between Bronze and White genotypes, and also male and female groups .

\section{Results}

\section{Growth}

The means of the body weights up to the age of eighteen weeks are shown in Table 1 . The investigation of the data for body weights had shown that there were significant differences between Bronze and White turkey genotypes and between sexes. The average body weights of Bronze (male-female) and White (male-female) turkeys were 5065.0-3799.0 and 10122.0-8330.9 $\mathrm{g}$ at 14 weeks and also 7495.0-4843.0 and 15844.0-11797.0 $\mathrm{g}$ at 18 weeks, respectively. In this way, the averaged body weights for females of Bronze and White turkeys were statistically $(\mathrm{P}<0.05)$ lower than their male's. On the other hand, the body weights of White turkey's males and females were statistically $(\mathrm{P}<0.05)$ higher than males and females of Bronze turkeys. There were $1 / 2$ differences between Bronze and White turkeys. It can be said that this was completely happened due to the different genotypes. Furthermore, in the first seven weeks of live 
turkeys had a very low intensive growth rate. The highest daily gain of body weight was found at the age of 9-18 weeks. At the age of 18 weeks turkeys had reached almost $80 \%$ of the adult weight.

Table 1

Average body weights of Bronze and White turkeys (g) (Durchschnittliches Körpergewicht der bronzefarbenen Puten und der weißen Puten)

\begin{tabular}{|c|c|c|c|c|c|}
\hline Age, weeks & Sex & $\mathrm{n}$ & $\begin{array}{l}\text { Bronze turkey } \\
\bar{X} \pm S_{\bar{X}}\end{array}$ & $\mathrm{n}$ & $\begin{array}{l}\text { White turkey } \\
\bar{X} \pm S_{\bar{X}}\end{array}$ \\
\hline \multirow[t]{2}{*}{0 (daily) } & $\mathrm{M}$ & 24 & $58.2 \pm 1.1^{\mathrm{b}}$ & 22 & $65.0 \pm 1.2^{\mathrm{a}}$ \\
\hline & $\mathrm{F}$ & 21 & $58.0 \pm 0.1^{\mathrm{b}}$ & 23 & $64.3 \pm 1.1^{\mathrm{a}}$ \\
\hline \multirow[t]{2}{*}{1} & M & 24 & $81.8 \pm 1.7^{\mathrm{b}}$ & 22 & $116.5 \pm 2.9^{\mathrm{a}}$ \\
\hline & $\mathrm{F}$ & 21 & $81.7 \pm 2.4^{b}$ & 23 & $116.2 \pm 1.2^{\mathrm{a}}$ \\
\hline \multirow[t]{2}{*}{3} & M & 24 & $290.4 \pm 7.8^{\mathrm{b}}$ & 22 & $362.6 \pm 10.3^{\mathrm{a}}$ \\
\hline & $\mathrm{F}$ & 21 & $269.6 \pm 10.1^{\mathrm{b}}$ & 23 & $363.4 \pm 8.1^{\mathrm{a}}$ \\
\hline \multirow[t]{2}{*}{5} & M & 24 & $723.6 \pm 24.0^{c}$ & 22 & $1160.6 \pm 30.9^{a}$ \\
\hline & $\mathrm{F}$ & 21 & $619.0 \pm 24.7^{\mathrm{d}}$ & 23 & $1063.7 \pm 21.4^{b}$ \\
\hline \multirow[t]{2}{*}{7} & M & 24 & $1399.1 \pm 91.6^{\mathrm{c}}$ & 22 & $2118.5 \pm 37.9^{\mathrm{a}}$ \\
\hline & $\mathrm{F}$ & 21 & $1071.1 \pm 41.0^{\mathrm{d}}$ & 23 & $1954.0 \pm 29.2^{\mathrm{b}}$ \\
\hline \multirow[t]{2}{*}{9} & M & 24 & $2121.7 \pm 75.1^{\mathrm{c}}$ & 22 & $3648.8 \pm 65.0^{\mathrm{a}}$ \\
\hline & $\mathrm{F}$ & 21 & $1685.0 \pm 59.7^{\mathrm{d}}$ & 23 & $3364.1 \pm 54.3^{\mathrm{b}}$ \\
\hline \multirow[t]{2}{*}{11} & M & 24 & $3280.0 \pm 113.0^{\mathrm{c}}$ & 22 & $5871.0 \pm 105.0^{\mathrm{a}}$ \\
\hline & $\mathrm{F}$ & 21 & $2554.3 \pm 81.9^{\mathrm{d}}$ & 23 & $5360.8 \pm 82.3^{\mathrm{b}}$ \\
\hline \multirow[t]{2}{*}{14} & M & 24 & $5065.0 \pm 142.0^{\mathrm{c}}$ & 22 & $10122.0 \pm 155.0^{\mathrm{a}}$ \\
\hline & $\mathrm{F}$ & 21 & $3799.0 \pm 11.0^{\mathrm{d}}$ & 23 & $8330.9 \pm 88.6^{\mathrm{b}}$ \\
\hline \multirow[t]{2}{*}{18} & M & 8 & $7495.0 \pm 427.0^{\mathrm{c}}$ & 3 & $15844.0 \pm 689.0^{\mathrm{a}}$ \\
\hline & $\mathrm{F}$ & 7 & $4843.0 \pm 167.0^{\mathrm{d}}$ & 5 & $11797.0 \pm 230.0^{b}$ \\
\hline
\end{tabular}

${ }^{a, b}=$ Different letters in the same column show significant difference $(\mathrm{P}<0.05) . \mathrm{M}=$ male, $\mathrm{F}=$ female

\section{Carcass traits}

At the age of 14 and 18 weeks the turkeys have been slaughtered and cut. The means of the carcass characteristics were shown in Table 2 and 3.

In this study; it was determined that the average percentage of carcass, breast and legs for males of Bronze-White turkeys were 72.4-81.6 \% and 74.0-82.7 \%g, 25.1-35.0\% and $28.5-39 \%, 28.1-27.8 \%$ and $31.3-27.4 \%$ and also $73.5-81.9 \%$ and $71.2-81.9 \%$, $25.5-36.9 \%$ and $26.3-35.5 \%, 26.8-25.7 \%$ and $29.1-27.3 \%$ for females at 14 and 18 weeks, respectively (Table 2).

In this way, White turkeys had the highest relative carcass weight (incl. edible organs) to body weight of live turkeys. However, male White turkeys had significant highest breast and leg percentages. Generally, the breast and legs percentage were statistically $(\mathrm{P}<0.05)$ higher in White turkeys than in Bronze turkeys, and also this case were same between males and females of all genotypes, too.

Differences of carcass percentage between males and females in genotypes were not significant both 14 and 18 weeks, but, significant between Bronze and White turkey genotypes, statistically $(\mathrm{P}<0.05)$.

It was the highest that the breast muscle percentage of females at 14 weeks and males of White turkeys at 18 weeks and legs muscle percentage of Bronze and White turkeys at 14 weeks and males of Bronze turkeys at 18 weeks.

The average percentages of wings, neck, back of females, heart, liver, gizzard, intestine, head, feed, feather, blood, etc. of Bronze turkeys were higher than White turkeys at 14 and 18 weeks in this study. 
Table 2

Composition of the body of Bronze and White turkeys (\%) (Zusammensetzung der Schlachtkörper von bronzefarbenen Puten und weißen Puten)

\begin{tabular}{|c|c|c|c|c|c|c|c|c|c|}
\hline \multirow{3}{*}{ Body parts } & \multirow[b]{3}{*}{ Sex } & \multicolumn{4}{|c|}{14 WEEKS } & \multicolumn{4}{|c|}{18 WEEKS } \\
\hline & & & Bronze & & White & & Bronze & & White \\
\hline & & $\mathrm{N}$ & $\bar{X} \pm S_{\bar{X}}$ & $\mathrm{n}$ & $\bar{X} \pm S_{\bar{X}}$ & $\mathrm{n}$ & $\bar{X} \pm S_{\bar{X}}$ & $\mathrm{n}$ & $\bar{X} \pm S_{\bar{X}}$ \\
\hline \multirow[t]{2}{*}{ Carcass/body } & $\mathrm{M}$ & 10 & $72.4 \pm 0.4^{b}$ & 11 & $81.6 \pm 0.4^{\mathrm{a}}$ & 6 & $74.0 \pm 0.3^{b}$ & 6 & $82.7 \pm 0.2^{\mathrm{a}}$ \\
\hline & $\mathrm{F}$ & 12 & $73.5 \pm 0.5^{\mathrm{b}}$ & 7 & $81.9 \pm 0.3^{\mathrm{a}}$ & 8 & $71.2 \pm 2.1^{\mathrm{b}}$ & 6 & $81.9 \pm 0.5^{\mathrm{a}}$ \\
\hline \multirow[t]{2}{*}{ Breast/carcass } & M & 10 & $25.1 \pm 0.3^{c}$ & 11 & $35.0 \pm 0.4^{\mathrm{b}}$ & 6 & $28.5 \pm 0.6^{c}$ & 6 & $39.0 \pm 0.7^{\mathrm{a}}$ \\
\hline & $\mathrm{F}$ & 12 & $25.5 \pm 0.2^{\mathrm{c}}$ & 7 & $36.9 \pm 0.4^{\mathrm{a}}$ & 8 & $26.3 \pm 0.6^{\mathrm{d}}$ & 6 & $35.5 \pm 0.8^{\mathrm{b}}$ \\
\hline \multirow[t]{2}{*}{ Legs/carcass } & M & 10 & $28.1 \pm 0.1^{\mathrm{a}}$ & 11 & $27.8 \pm 0.2^{\mathrm{a}}$ & 6 & $31.3 \pm 0.6^{\mathrm{a}}$ & 6 & $27.4 \pm 0.2^{\mathrm{c}}$ \\
\hline & $\mathrm{F}$ & 12 & $26.8 \pm 0.2^{\mathrm{b}}$ & 7 & $25.7 \pm 0.3^{c}$ & 8 & $29.1 \pm 0.4^{b}$ & 6 & $27.3 \pm 0.3^{\mathrm{c}}$ \\
\hline \multirow[t]{2}{*}{ Wings/carcass } & M & 10 & $15.8 \pm 0.3^{\mathrm{a}}$ & 11 & $12.9 \pm 0.3^{\mathrm{c}}$ & 6 & $13.1 \pm 0.1^{\mathrm{a}}$ & 6 & $11.0 \pm 0.0^{\mathrm{c}}$ \\
\hline & $\mathrm{F}$ & 12 & $14.5 \pm 0.2^{\mathrm{b}}$ & 7 & $11.6 \pm 0.2^{\mathrm{d}}$ & 8 & $12.5 \pm 0.1^{\mathrm{b}}$ & 6 & $10.4 \pm 0.2^{\mathrm{d}}$ \\
\hline \multirow[t]{2}{*}{ Neck/carcass } & M & 10 & $8.1 \pm 0.1^{\mathrm{a}}$ & 11 & $5.9 \pm 0.1^{\mathrm{c}}$ & 6 & $8.7 \pm 0.1^{\mathrm{a}}$ & 6 & $7.3 \pm 0.4^{\mathrm{b}}$ \\
\hline & $\mathrm{F}$ & 12 & $6.9 \pm 0.2^{\mathrm{b}}$ & 7 & $5.7 \pm 0.1^{\mathrm{c}}$ & 8 & $9.0 \pm 0.4^{\mathrm{a}}$ & 6 & $5.9 \pm 0.2^{\mathrm{c}}$ \\
\hline \multirow[t]{2}{*}{ Back/carcass } & M & 10 & $22.9 \pm 0.3^{\mathrm{b}}$ & 11 & $18.4 \pm 0.3^{\mathrm{d}}$ & 6 & $18.4 \pm 0.2^{c}$ & 6 & $15.4 \pm 0.2^{\mathrm{d}}$ \\
\hline & $\mathrm{F}$ & 12 & $26.3 \pm 0.4^{\mathrm{a}}$ & 7 & $20.2 \pm 0.4^{\mathrm{c}}$ & 8 & $22.4 \pm 0.5^{\mathrm{a}}$ & 6 & $20.9 \pm 0.7^{b}$ \\
\hline \multirow[t]{2}{*}{ Heart/body } & M & 10 & $0.77 \pm 0.01^{\mathrm{a}}$ & 11 & $0.71 \pm 0.02^{\mathrm{ab}}$ & 6 & $0.76 \pm 0.02^{\mathrm{a}}$ & 6 & $0.53 \pm 0.01^{\mathrm{c}}$ \\
\hline & $\mathrm{F}$ & 12 & $0.75 \pm 0.05^{\mathrm{a}}$ & 7 & $0.64 \pm 0.04^{\mathrm{b}}$ & 8 & $0.63 \pm 0.04^{b}$ & 6 & $0.50 \pm 0.02^{\mathrm{c}}$ \\
\hline \multirow[t]{2}{*}{ Liver/body } & M & 10 & $2.46 \pm 0.11^{\mathrm{a}}$ & 11 & $1.85 \pm 0.08^{\mathrm{b}}$ & 6 & $1.67 \pm 0.02^{\mathrm{b}}$ & 6 & $1.18 \pm 0.04^{\mathrm{c}}$ \\
\hline & $\mathrm{F}$ & 12 & $2.71 \pm 0.11^{\mathrm{a}}$ & 7 & $1.93 \pm 0.10^{\mathrm{b}}$ & 8 & $2.04 \pm 0.11^{\mathrm{a}}$ & 6 & $1.49 \pm 0.06^{\mathrm{b}}$ \\
\hline \multirow[t]{2}{*}{ Gizzard/body } & M & 10 & $5.91 \pm 0.22^{\mathrm{a}}$ & 11 & $3.06 \pm 0.20^{\mathrm{b}}$ & 6 & $4.35 \pm 0.31^{b}$ & 6 & $2.09 \pm 0.11^{\mathrm{d}}$ \\
\hline & $\mathrm{F}$ & 12 & $6.03 \pm 0.18^{\mathrm{a}}$ & 7 & $3.38 \pm 0.12^{\mathrm{b}}$ & 8 & $5.80 \pm 0.19^{\mathrm{a}}$ & 6 & $2.97 \pm 0.33^{\mathrm{c}}$ \\
\hline \multirow[t]{2}{*}{ Intestine/body } & M & 10 & $5.29 \pm 0.17^{\mathrm{b}}$ & 11 & $4.43 \pm 0.15^{\mathrm{c}}$ & 6 & $4.55 \pm 0.07^{b}$ & 6 & $3.13 \pm 0.03^{\mathrm{d}}$ \\
\hline & $\mathrm{F}$ & 12 & $5.93 \pm 0.28^{\mathrm{a}}$ & 7 & $4.72 \pm 0.15^{b}$ & 8 & $6.19 \pm 0.16^{\mathrm{a}}$ & 6 & $4.01 \pm 0.21^{\mathrm{c}}$ \\
\hline \multirow[t]{2}{*}{ Head/body } & M & 10 & $2.07 \pm 0.07^{\mathrm{a}}$ & 11 & $1.45 \pm 0.06^{\mathrm{b}}$ & 6 & $1.91 \pm 0.11^{\mathrm{a}}$ & 6 & $1.21 \pm 0.03^{\mathrm{c}}$ \\
\hline & $\mathrm{F}$ & 12 & $2.12 \pm 0.07^{\mathrm{a}}$ & 7 & $1.29 \pm 0.03^{b}$ & 8 & $1.63 \pm 0.03^{b}$ & 6 & $1.04 \pm 0.03^{\mathrm{d}}$ \\
\hline \multirow[t]{2}{*}{ Feed/body } & M & 10 & $4.04 \pm 0.12^{\mathrm{a}}$ & 11 & $3.59 \pm 0.07^{b}$ & 6 & $3.75 \pm 0.01^{\mathrm{a}}$ & 6 & $2.95 \pm 0.03^{\mathrm{b}}$ \\
\hline & $\mathrm{F}$ & 12 & $3.77 \pm 0.18^{\mathrm{ab}}$ & 7 & $2.74 \pm 0.03^{\mathrm{c}}$ & 8 & $2.96 \pm 0.09^{\mathrm{b}}$ & 6 & $2.35 \pm 0.07^{\mathrm{c}}$ \\
\hline \multirow{2}{*}{$\begin{array}{l}\text { Blood, weather } \\
\text { and, etc. / body }\end{array}$} & $\mathrm{M}$ & 10 & $11.05 \pm 0.45^{\mathrm{a}}$ & 11 & $5.15 \pm 0.27^{\mathrm{c}}$ & 6 & $12.02 \pm 0.25^{\mathrm{a}}$ & 6 & $7.42 \pm 0.05^{\mathrm{b}}$ \\
\hline & $\mathrm{F}$ & 12 & $9.33 \pm 0.36^{\mathrm{b}}$ & 7 & $5.34 \pm 0.32^{\mathrm{c}}$ & 8 & $13.89 \pm 2.30^{\mathrm{a}}$ & 6 & $7.37 \pm 0.31^{b}$ \\
\hline
\end{tabular}

$\bar{a}=$ Different letters in the same column show significant difference $(\mathrm{P}<0.05) . \mathrm{M}=$ male, $\mathrm{F}=$ female.

The investigation of the data had shown that average carcass weights for males of Bronze and White turkeys at 18 weeks were 5445.0 and $13107.0 \mathrm{~g}$, and also 3548.0 and $9676.0 \mathrm{~g}$ for females (Table 3).

Differences of carcass weights were statistically significant $(\mathrm{P}<0.05)$ between genotypes and between sexes of Bronze and White turkeys.

In this study, the average weights of breast, legs, wings, neck, back and edible viscera were 1550.0 to $940.5 \mathrm{~g}, 1705.3$ to $1036.5 \mathrm{~g}, 713.3$ to $443.0 \mathrm{~g}, 474.0$ to $318.0 \mathrm{~g}, 1002.0$ to $791.5 \mathrm{~g}$ and 368.0 to $299.9 \mathrm{~g}$ of Bronze turkeys, and also 5092.0 to $3430.0 \mathrm{~g}, 3593.0$ to $2641.3 \mathrm{~g}, 1436.7$ to $1006.7 \mathrm{~g}, 959.3$ to $574.0 \mathrm{~g}, 2025.3$ to $2024.0 \mathrm{~g}$ and 494.6 to $478.1 \mathrm{~g}$ of White turkeys at 18 weeks of age, respectively.

Differences of body part weights were statistically significant $(\mathrm{P}<0.05)$ between genotypes and between sexes of Bronze and White turkeys.

\section{Nutrient content of meat}

In this study, average percentages of crude protein content and crude fat content for breast and legs muscle meats in Bronze and White turkeys at 14 and 18 weeks of age were investigated and the results were showed in Table 4. 
Table 3

Body parts of Bronze and White turkeys (g) (Teilstücke von bronzefarbenen Puten und weißen Puten)

\begin{tabular}{|c|c|c|c|c|c|c|c|c|c|}
\hline \multirow{3}{*}{ Body parts } & \multirow[b]{3}{*}{ Sex } & \multicolumn{4}{|c|}{14 WEEKS } & \multicolumn{4}{|c|}{18 WEEKS } \\
\hline & & \multicolumn{2}{|r|}{ Bronze } & \multicolumn{2}{|c|}{ White } & \multicolumn{2}{|r|}{ Bronze } & \multicolumn{2}{|c|}{ White } \\
\hline & & $\mathrm{N}$ & $\bar{X} \pm S_{\bar{X}}$ & $\mathrm{n}$ & $\bar{X} \pm S_{\bar{X}}$ & $\mathrm{n}$ & $\bar{X} \pm S_{\bar{X}}$ & $\mathrm{n}$ & $\bar{X} \pm S_{\bar{X}}$ \\
\hline \multirow[t]{2}{*}{ Carcass } & M & 10 & $3610.0 \pm 104.0^{c}$ & 11 & $8285.3 \pm 198.0^{\mathrm{a}}$ & 6 & $5445.0 \pm 130.0^{c}$ & 6 & $13107.0 \pm 387^{\mathrm{a}}$ \\
\hline & $\mathrm{F}$ & 12 & $2898.3 \pm 114.0^{\mathrm{d}}$ & 7 & $6721.7 \pm 85.9^{\mathrm{b}}$ & 8 & $3548.0 \pm 207.0^{\mathrm{d}}$ & 6 & $9676.0 \pm 188.0^{b}$ \\
\hline \multirow[t]{2}{*}{ Breast } & M & 10 & $910.0 \pm 36.7^{\mathrm{c}}$ & 11 & $2900.0 \pm 84.0^{\mathrm{a}}$ & 6 & $1550.0 \pm 46.1^{\mathrm{c}}$ & 6 & $5092.0 \pm 54.4^{\mathrm{a}}$ \\
\hline & $\mathrm{F}$ & 12 & $738.3 \pm 30.8^{c}$ & 7 & $2477.7 \pm 40.4^{\mathrm{b}}$ & 8 & $940.5 \pm 72.1^{\mathrm{d}}$ & 6 & $3430.0 \pm 94.3^{b}$ \\
\hline \multirow[t]{2}{*}{ Legs } & M & 10 & $1016.0 \pm 29.6^{c}$ & 11 & $2300.2 \pm 45.0^{\mathrm{a}}$ & 6 & $1705.3 \pm 59.8^{c}$ & 6 & $3593.0 \pm 132.0^{\mathrm{a}}$ \\
\hline & $\mathrm{F}$ & 12 & $775.0 \pm 29.6^{\mathrm{d}}$ & 7 & $1729.1 \pm 23.1^{\mathrm{b}}$ & 8 & $1036.5 \pm 67.3^{d}$ & 6 & $2641.3 \pm 61.4^{\mathrm{b}}$ \\
\hline \multirow[t]{2}{*}{ Wings } & M & 10 & $568.0 \pm 14.2^{\mathrm{c}}$ & 11 & $1068.5 \pm 27.4^{\mathrm{a}}$ & 6 & $713.3 \pm 12.4^{\mathrm{c}}$ & 6 & $1436.7 \pm 39.1^{\mathrm{a}}$ \\
\hline & $\mathrm{F}$ & 12 & $423.3 \pm 21.4^{\mathrm{d}}$ & 7 & $776.9 \pm 19.1^{\mathrm{b}}$ & 8 & $443.0 \pm 24.6^{\mathrm{d}}$ & 6 & $1006.7 \pm 7.9^{\mathrm{b}}$ \\
\hline \multirow[t]{2}{*}{ Neck } & M & 10 & $292.0 \pm 6.8^{\mathrm{c}}$ & 11 & $490.2 \pm 15.4^{\mathrm{a}}$ & 6 & $474.0 \pm 16.1^{\mathrm{c}}$ & 6 & $959.3 \pm 74.1^{\mathrm{a}}$ \\
\hline & $\mathrm{F}$ & 12 & $201.7 \pm 11.1^{\mathrm{d}}$ & 7 & $382.0 \pm 8.4^{\mathrm{b}}$ & 8 & $318.0 \pm 23.0^{\mathrm{d}}$ & 6 & $574.0 \pm 17.8^{\mathrm{b}}$ \\
\hline \multirow[t]{2}{*}{ Back } & M & 10 & $824.0 \pm 23.8^{\mathrm{c}}$ & 11 & $1526.4 \pm 54.5^{\mathrm{a}}$ & 6 & $1002.0 \pm 18.4^{\mathrm{b}}$ & 6 & $2025.3 \pm 87.3^{\mathrm{a}}$ \\
\hline & $\mathrm{F}$ & 12 & $760.0 \pm 25.8^{\mathrm{c}}$ & 7 & $1356.0 \pm 35.2^{\mathrm{b}}$ & 8 & $791.5 \pm 41.5^{\mathrm{c}}$ & 6 & $2024.0 \pm 92.4^{\mathrm{a}}$ \\
\hline \multirow[t]{2}{*}{ Heart } & M & 10 & $27.6 \pm 0.9^{c}$ & 11 & $59.1 \pm 2.8^{\mathrm{a}}$ & 6 & $41.3 \pm 0.8^{\mathrm{c}}$ & 6 & $69.3 \pm 0.4^{\mathrm{a}}$ \\
\hline & $\mathrm{F}$ & 12 & $21.7 \pm 1.4^{\mathrm{c}}$ & 7 & $42.9 \pm 3.2^{\mathrm{b}}$ & 8 & $22.8 \pm 2.6^{\mathrm{d}}$ & 6 & $48.7 \pm 2.2^{\mathrm{b}}$ \\
\hline \multirow[t]{2}{*}{ Liver } & M & 10 & $89.2 \pm 5.6^{\mathrm{c}}$ & 11 & $153.5 \pm 8.6^{\mathrm{a}}$ & 6 & $90.7 \pm 2.2^{b}$ & 6 & $154.0 \pm 0.7^{\mathrm{a}}$ \\
\hline & $\mathrm{F}$ & 12 & $78.0 \pm 3.5^{\mathrm{c}}$ & 7 & $130.3 \pm 8.0^{\mathrm{b}}$ & 8 & $73.8 \pm 7.9^{c}$ & 6 & $143.7 \pm 5.2^{\mathrm{a}}$ \\
\hline \multirow[t]{2}{*}{ Gizzard } & M & 10 & $211.6 \pm 4.9^{\mathrm{b}}$ & 11 & $252.7 \pm 15.8^{\mathrm{a}}$ & 6 & $236.0 \pm 16.8^{b}$ & 6 & $271.3 \pm 5.9^{\mathrm{ab}}$ \\
\hline & $\mathrm{F}$ & 12 & $175.7 \pm 10.1^{\mathrm{c}}$ & 7 & $227.1 \pm 9.4^{\mathrm{ab}}$ & 8 & $203.3 \pm 7.1^{\mathrm{c}}$ & 6 & $285.7 \pm 29.2^{\mathrm{a}}$ \\
\hline \multirow[t]{2}{*}{ Intestine } & M & 10 & $190.4 \pm 6.7^{\mathrm{c}}$ & 11 & $367.5 \pm 15.5^{\mathrm{a}}$ & 6 & $247.3 \pm 4.2^{\mathrm{b}}$ & 6 & $409.3 \pm 8.8^{\mathrm{a}}$ \\
\hline & $\mathrm{F}$ & 12 & $171.0 \pm 9.0^{\mathrm{c}}$ & 7 & $317.4 \pm 12.0^{\mathrm{b}}$ & 8 & $217.5 \pm 8.6^{\mathrm{c}}$ & 6 & $386.7 \pm 17.1^{\mathrm{a}}$ \\
\hline \multirow[t]{2}{*}{ Head } & M & 10 & $103.2 \pm 3.6^{\mathrm{b}}$ & 11 & $146.4 \pm 3.5^{\mathrm{a}}$ & 6 & $140.0 \pm 5.1^{\mathrm{b}}$ & 6 & $192.7 \pm 9.9^{\mathrm{a}}$ \\
\hline & $\mathrm{F}$ & 12 & $83.3 \pm 3.7^{\mathrm{c}}$ & 7 & $105.7 \pm 1.7^{\mathrm{b}}$ & 8 & $80.8 \pm 3.0^{\mathrm{d}}$ & 6 & $122.3 \pm 2.9^{c}$ \\
\hline \multirow[t]{2}{*}{ Feed } & M & 10 & $201.2 \pm 8.0^{\mathrm{c}}$ & 11 & $363.1 \pm 8.3^{\mathrm{a}}$ & 6 & $276.0 \pm 5.7^{\mathrm{b}}$ & 6 & $466.0 \pm 8.03^{\mathrm{a}}$ \\
\hline & $\mathrm{F}$ & 12 & $148.0 \pm 8.1^{\mathrm{d}}$ & 7 & $224.9 \pm 5.0^{\mathrm{b}}$ & 8 & $146.8 \pm 6.7^{\mathrm{c}}$ & 6 & $277.0 \pm 6.9^{\mathrm{b}}$ \\
\hline \multirow{2}{*}{$\begin{array}{l}\text { Blood, } \\
\text { weather, etc. }\end{array}$} & M & 10 & $546.8 \pm 17.9^{\mathrm{a}}$ & 11 & $522.9 \pm 31.1^{\mathrm{a}}$ & 6 & $884.0 \pm 18.3^{\mathrm{b}}$ & 6 & $1174.7 \pm 28.4^{\mathrm{a}}$ \\
\hline & $\mathrm{F}$ & 12 & $365.7 \pm 16.1^{\mathrm{c}}$ & 7 & $438.9 \pm 28.0^{\mathrm{b}}$ & 8 & $665.7 \pm 85.8^{c}$ & 6 & $870.3 \pm 41.0^{\mathrm{b}}$ \\
\hline
\end{tabular}

$\overline{a, b}=$ Different letters in the same column show significant difference $(\mathrm{P}<0.05) . \mathrm{M}=$ male, $\mathrm{F}=$ female

Table 4

Protein and fat content of breast and legs muscle of Bronze and White turkeys at the age of 14 and 18 weeks (\%) (Protein- und Fettgehalt des Muskelfleisches von Brust und Schenkel der bronzefarbenen Puten und weißen Puten im Alter von 14 und 18 Wochen)

\begin{tabular}{|c|c|c|c|c|c|c|c|c|c|}
\hline \multirow{3}{*}{ Quality traits } & \multirow[b]{3}{*}{ Sex } & \multicolumn{4}{|c|}{$14 \mathrm{WEEKS}$} & \multicolumn{4}{|c|}{18 WEEKS } \\
\hline & & & Bronze $\bar{X} \pm S_{\bar{y}}$ & & White & & Bronze & & White \\
\hline & & $\mathrm{n}$ & & $\mathrm{n}$ & $\bar{X} \pm S_{\bar{X}}$ & $\mathrm{~N}$ & $\bar{X} \pm S_{\bar{X}}$ & $\mathrm{n}$ & $\bar{X} \pm S_{\bar{X}}$ \\
\hline \multicolumn{10}{|l|}{ Protein } \\
\hline \multirow[t]{2}{*}{ Breast } & M & 3 & $14.5 \pm 0.54^{\mathrm{ef}}$ & 3 & $17.2 \pm 0.05^{\mathrm{de}}$ & 3 & $23.0 \pm 0.97^{\mathrm{b}}$ & 3 & $16.5 \pm 1.03^{\mathrm{de}}$ \\
\hline & $\mathrm{F}$ & 3 & $19.6 \pm 2.16^{\mathrm{cd}}$ & 3 & $17.6 \pm 0.09^{\mathrm{de}}$ & 3 & $26.1 \pm 0.64^{\mathrm{a}}$ & 3 & $17.4 \pm 1.26^{\mathrm{de}}$ \\
\hline \multirow[t]{2}{*}{ Leg } & M & 3 & $14.5 \pm 1.41^{\mathrm{ef}}$ & 3 & $14.9 \pm 0.40^{\mathrm{ef}}$ & 3 & $19.0 \pm 0.96^{\mathrm{cd}}$ & 3 & $13.3 \pm 0.38^{f}$ \\
\hline & $\mathrm{F}$ & 3 & $15.7 \pm 0.95^{\mathrm{ef}}$ & 3 & $15.7 \pm 0.72^{\mathrm{ef}}$ & 3 & $21.2 \pm 0.83^{\mathrm{bc}}$ & 3 & $14.8 \pm 0.37^{\mathrm{ef}}$ \\
\hline \multicolumn{10}{|l|}{ Fat } \\
\hline \multirow[t]{2}{*}{ Breast } & M & 3 & $0.08 \pm 0.01^{\mathrm{c}}$ & 3 & $0.22 \pm 0.05^{\mathrm{c}}$ & 3 & $1.04 \pm 0.55^{\mathrm{bc}}$ & 3 & $0.15 \pm 0.04^{\mathrm{c}}$ \\
\hline & $\mathrm{F}$ & 3 & $0.08 \pm 0.02^{\mathrm{c}}$ & 3 & $0.20 \pm 0.04^{c}$ & 3 & $1.46 \pm 0.67^{b c}$ & 3 & $0.44 \pm 0.17^{\mathrm{c}}$ \\
\hline \multirow[t]{2}{*}{ Leg } & M & 3 & $0.25 \pm 0.10^{\mathrm{c}}$ & 3 & $0.70 \pm 0.23^{\mathrm{bc}}$ & 3 & $2.10 \pm 0.60^{\mathrm{b}}$ & 3 & $0.65 \pm 0.27^{\mathrm{bc}}$ \\
\hline & $\mathrm{F}$ & 3 & $0.37 \pm 0.04^{\mathrm{c}}$ & 3 & $0.64 \pm 0.23^{\mathrm{bc}}$ & 3 & $3.58 \pm 1.53^{\mathrm{a}}$ & 3 & $0.64 \pm 0.12^{\mathrm{bc}}$ \\
\hline
\end{tabular}

$=$ Different letters in the same column show significant difference $(\mathrm{P}<0.05) . \mathrm{M}=$ male, $\mathrm{F}=$ female

In the table that average percentages of crude protein were 23.0 to $26.1 \%$ and 16.5 $17.4 \%$ for males-females of Bronze and White turkeys's breast muscles meat and also 19.0 to $21.2 \%$ and 13.3 to $14.8 \%$ for legs muscle meat, and the average percentages 
of crude fat were 1.04 to $1.46 \%$ and 0.15 to $0.44 \%$ for breast and also 2.10 to $3.58 \%$ and 0.65 to $0.64 \%$ for legs at 18 weeks, respectively.

Statistical analyses generally showed that crude protein content were high in each genotypes breast muscle meat according to legs muscle meat as males and females. However, crude protein content of breast muscle meat and crude fat content of legs muscle meat were lower than Bronze turkeys.

\section{Feed consume}

The averages of feed intake, weight gain, feed conversion ratios of Bronze and White turkeys were investigated as weekly and the results were shown in Table 5.

Table 5

Feed intakes, weight gains and feed conversion ratios of Bronze and White turkeys (Futteraufnahme, Gewichtszunahme und Futteraufwand von bronzefarbenen und weißen Puten)

\begin{tabular}{|c|c|c|c|c|c|c|c|c|}
\hline \multirow[b]{2}{*}{ Weeks } & \multicolumn{4}{|c|}{ Bronze turkey } & \multicolumn{4}{|c|}{ White turkey } \\
\hline & $\mathrm{n}^{*}$ & $\begin{array}{l}\text { Feed } \\
\text { intake }^{1} \\
(\mathrm{~g} / \mathrm{b} / \mathrm{wk})\end{array}$ & $\begin{array}{l}\text { Weight } \\
\text { gain } \\
\text { (g/b/wk) }\end{array}$ & $\begin{array}{l}\text { Feed conv. ratio } \\
\text { (feed/gain/week) }\end{array}$ & $\mathrm{n}^{*}$ & $\begin{array}{l}\text { Feed } \\
\text { intake }^{1} \\
(\mathrm{~g} / \mathrm{b} / \mathrm{wk})\end{array}$ & $\begin{array}{l}\text { Weight } \\
\text { gain } \\
(\mathrm{g} / \mathrm{b} / \mathrm{wk})\end{array}$ & $\begin{array}{l}\text { Feed conv. ratio } \\
\text { (feed/gain/week) }\end{array}$ \\
\hline 1 & 45 & 32 & 23.64 & 1.35 & 45 & 72 & 51.71 & 1.39 \\
\hline 3 & 45 & 284 & 198.94 & 1.43 & 45 & 410 & 246.66 & 1.66 \\
\hline 5 & 45 & 600 & 394.10 & 1.52 & 45 & 1310 & 748.06 & 1.75 \\
\hline 7 & 45 & 996 & 589.24 & 1.69 & 45 & 1828 & 923.35 & 1.98 \\
\hline 9 & 45 & 1204 & 653.88 & 1.84 & 45 & 3116 & 1468.87 & 2.12 \\
\hline 11 & 45 & 2170 & 1023.43 & 2.12 & 45 & 4720 & 2106.94 & 2.24 \\
\hline 14 & 45 & 3820 & 1532.86 & 2.69 & 45 & 9064 & 3596.32 & 2.52 \\
\hline 18 & 23 & 5390 & 1783.20 & 3.02 & 27 & 12660 & 4108.08 & 3.08 \\
\hline
\end{tabular}

$\mathrm{n}^{*}$, number of animals.

1 , feed intake measured as total feed intake of group and expressed as feed intake per bird.

${ }^{2}$, weight gain measured as subtracting the weight of birds at the end of the specified week from that of the beginning of week, and expressed as mean of the group.

In the table, average feed intake, weight gain of White turkeys were 9064, $3596.32 \mathrm{~g}$ for each bird at 14 weeks and 12660, $4108.08 \mathrm{~g}$ at 18 weeks; 3820, $1532.86 \mathrm{~g}$ at 14 weeks and 5390, $1783.20 \mathrm{~g}$ at 18 weeks for Bronze turkeys, respectively.

The average feed intake, weight gain of White turkeys were higher than Bronze turkeys.

\section{Discussion}

Growth

In the literature data of body weights that they averaged 14405 to $15676 \mathrm{~g}$ of turkeys at 20 weeks (MEIJERHOF, 1973); 4150 and $3650 \mathrm{~g}$ of Beltswille White and Broad Breasted White turkeys at 12 weeks and also 5700 and $5000 \mathrm{~g}$ at 16 weeks (GANSEL and NEUBAUER, 1974); 4710 to $5320 \mathrm{~g}$ of Beltswille White turkeys at 13 weeks (POPESCU-VIFOR and PUSCATU, 1979); 12300 to $10610 \mathrm{~g}$ for males and 7490 to $7910 \mathrm{~g}$ for females of White and Bronze turkeys at 25 weeks (MARQUEZ at al., 1983); 7.8-8.2 kg for males and 5.6-6.0 kg for females of Large Breasted Bronze turkeys and 9.8 and $7.2 \mathrm{~kg}$ of White Nicholas turkeys at 16 weeks (KOCAK, 1984); 4420.0, 5309.0, 6104,6 g of Betina turkeys at 16, 18, 20 weeks and also 4870.0, $5818.4,6682.0 \mathrm{~g}$ of Bronze X Betina turkeys, respectively (TURKOGLU et al., 1990); $10-12 \mathrm{~kg}$ for males and $5-7 \mathrm{~kg}$ for females of Bronze turkeys at 28 weeks (TURKOGLU et al., 1991); 4324.5-2695.5 g of Bronze turkey for males-females at 18 
weeks (SARICA et al., 1991b); 4416.9, 4799.4, 5547.0 $\mathrm{g}$ of Bronze turkeys at 16, 18, 20 weeks (SARICA et al., 1991a); 3225.5-2359.7, 5323.5-3816.7 g of Bronze turkeys for males-females at 14, 18 weeks (TESTIK and CELEN, 1993); 5860.0-5200.0 $\mathrm{g}$ of Canadian Hybrid Turkeys at 14 weeks and 7020.0-6025.0 $\mathrm{g}$ at 18 weeks (CELEN and TESTIK, 1995); $7 \mathrm{~kg}$ of Bronze turkeys (AKSOY and ISCAN, 1995); 10575 and 6877 $\mathrm{g}$ for males and females of Bronze turkeys at 24 weeks (AKSOY, 1996); 5170.3$3927.8 \mathrm{~g}, 7282.7-5022.4 \mathrm{~g}$ of Bronze turkeys for males-females at 16, 20 weeks (ISGUZAR and TESTIK, 2001); 3348.3-3064.2 $\mathrm{g}$ of Bronze turkeys at 16 weeks (SENGUL, 2001).

Generally, the studies related to body weight of Bronze turkeys in literature show between 7-9 and 5-6 kg at 18 weeks of age as males and females, respectively.

In this study, the body weight values of Bronze turkeys were similar to Beltsville White and Broad Breasted White turkeys (GANSEL and NEUBAUER, 1974) and to Bronze turkeys (AKSOY and ISCAN, 1995; AKSOY, 1996; MARQUEZ at al., 1983), and higher to Betina and Bronze X Betina turkeys (TURKOGLU et al., 1990) and to Bronze turkeys (TURKOGLU et al., 1991; SARICA et al., 1991a, 1991b; TESTIK and CELEN, 1993; ISGUZAR and TESTIK, 2001; SENGUL, 2001) and lower to White turkeys (MEIJERHOF, 1973) and to Beltsville White turkeys (POPESCU-VIFOR and PUSCATU, 1979) and to Bronze and White Nicholas turkeys (KOCAK, 1984) and to Canadian Hybrid turkeys (CELEN and TESTIK, 1995) and to turkeys (WISCHHUSEN, 1975). Differences of body weights between this study and literature data have due to different genotypes and feeding and growing conditions, management, etc.

\section{Carcass traits}

In the literature data of carcass percentages that they averaged $81.2 \%$ of Large White turkeys for males at 27 weeks and $79.5 \%$ for females at 24 weeks (MORAN et al., 1970); 73.4 and $72.5 \%$ of Bronze turkeys at 18 and 20 weeks (SARICA et al., 1991a); 73.6 and $73.2 \%$ of Bronze turkeys for males and females at 18 weeks (SARICA et al., 1991b); 80.5-78.8 and 86.7-83.0 \% of Bronze turkeys males-females at 14 and 18 weeks (TESTIK and CELEN, 1993); 85.8 and $85.3 \%$ of Buta turkeys at 17 and 19 weeks (ARABA and MIRELES, 1993); $80 \%$ of Bronze turkeys (AKSOY and ISCAN, 1995); 81.3 and $82.8 \%$ of Bronze turkeys for males and females at 24 weeks (AKSOY, 1996); 70.0 to $71.0 \%$ of Bronze turkeys at 16 weeks (SENGUL, 2001); 77.5 and $77.6 \%$ of Bronze turkeys for males and females at 28 weeks (ISGUZAR and TESTIK, 2001). In this study, the carcass percentage values were similar to (SALMON, 1974, 1979; SARICA et al., 1991a, b; SENGUL, 2001; ISGUZAR and TESTIK, 2001), and higher to (MORAN et al., 1970), and lower to (TESTIK and CELEN, 1993; ARABA and MIRELES, 1993; AKSOY and ISCAN, 1995; AKSOY, 1996).

In literature data of breast muscle percentages were 16.7 and $20.3 \%$ of turkeys at 16 and 18 weeks (GILLIS et al., 1973); 28.1-29.4 \% of Bronze turkey for males-females at 18 weeks (SARICA et al., 1991b); 37.31 and $38.71 \%$ of Large White turkeys for males and females (LESSON and SUMMERS, 1997); 32.1-28.5 \% of Bronze turkeys for males-females at 28 weeks (ISGUZAR and TESTIK, 2001). In the study, the breast muscle percentage values were similar to Bronze turkeys (SARICA et al., 1991b) and 
to Large White turkeys (LESSON and SUMMERS, 1997) for White turkeys, and lower to Bronze turkeys (ISGUZAR and TESTIK, 2001).

In literature data of legs muscle percentages were 31.1-30.6\% of Bronze turkeys for males-females at 18 weeks (SARICA et al., 1991b); 15.1 and $15.4 \%$ of Large White turkeys for males and females of tight percentages (LESSON and SUMMERS, 1997); 27.9-27.8 \% of Bronze turkeys for males-females at 28 weeks (ISGUZAR and TESTIK, 2001). In the study, the legs muscle percentage values were similar to Bronze turkeys (SARICA et al., 1991b) and to Large White turkeys (LESSON and SUMMERS, 1997) for White turkeys, and higher to Bronze turkeys (ISGUZAR and TESTIK, 2001).

Furthermore, researches reported that the average percentage of breast+back were 54.2 and $53.7 \%$ of Middle Heavy White turkeys for males and females at 18 weeks (SALMON, 1979); 44.0 and $44.3 \%$ of Buta turkeys for males(toms) of breast+thigh+wings+drums at 17 and 19 weeks (ARABA and MIRELES, 1993); 52.7 and $49.4 \%$ of Bronze turkeys for males and females of breast+back at 24 weeks (AKSOY, 1996). In the study, the legs muscle percentage values were similar to Middle Heavy White turkeys (SALMON, 1979) and Bronze turkeys (AKSOY, 1996)., and higher to Buta turkeys (ARABA and MIRELES, 1993).

On the other hand, in literature, the some informations of turkey body parts was reported by researches that average percentages of wings, neck, back, edible and total viscera.

In literature data, the average percentages of wings were 13.1 and $12.7 \%$ of to Bronze turkeys for males and females at 18 weeks (SARICA et al., 1991b); 8.6 and $8.6 \%$ of Buta turkeys at 17 and 19 weeks to (ARABA and MIRELES, 1993); 10.4 and $10.7 \%$ of Bronze turkeys for males and females at 24 weeks (AKSOY, 1996); 14.50 and $13.93 \%$ of Large White turkeys for males and females (LESSON and SUMMERS, 1997); 9.9 and $10.9 \%$ of Bronze turkeys for males and females at 28 weeks (ISGUZAR and TESTIK, 2001). In the study, wings percentage values were similar to (SARICA et al., 1991b; ISGUZAR and TESTIK, 2001), and higher to (ARABA and MIRELES, 1993; AKSOY, 1996), and lower to LESSON and SUMMERS (1997).

The average percentages of neck were $7.4 \%$ of the Large White turkeys for males at 25 weeks and $6.1 \%$ for females at 24 weeks (MORAN et al., 1970); $2.2 \%$ of turkeys (KOCAK, 1984); 9.2 and $8.6 \%$ of Bronze turkeys for males and females at 18 weeks (SARICA et al., 1991b); 4.5 and 5.0\% of Bronze turkeys for males and females at 24 weeks (AKSOY, 1996); 13.4 and $7.6 \%$ of Bronze turkeys for males and females at 28 weeks (ISGUZAR and TESTIK, 2001). In the study, the neck percentage values were similar to (MORAN et al., 1970; SARICA et al., 1991b; ISGUZAR and TESTIK, 2001;), and higher to (KOCAK, 1984; AKSOY, 1996).

The average back percentages were 18.4 and $19.2 \%$ for males and females of Bronze turkeys at 18 weeks (SARICA et al., 1991b); 16.7 and 25.2\% for males and females of Bronze turkeys at 28 weeks (ISGUZAR and TESTIK, 2001). In the study, the back percentage values were similar to literature data.

The average percentages of edible viscera were $2.2 \%$ of turkeys (KOCAK, 1984); 3.5 and $2.7 \%$ of Large White turkeys at 12 and 20 weeks (FERKET and SELL, 1989); 5.3 and $5.9 \%$ of Bronze turkeys for males and females at 18 weeks (SARICA et al., 1991b); 5.0 and 5.2\% of Bronze turkeys for males and females at 24 weeks (AKSOY, 1996); 4.0 and $4.6 \%$ of Bronze turkeys for males and females at 28 weeks (ISGUZAR 
and TESTIK, 2001), and 7.47 and $8.42 \%$ for total viscera of Large White turkeys's males and females (LESSON and SUMMERS, 1997). In the study, generally, the edible viscera percentage values were higher than in literature data, and lower for total viscera.

The values of average body parts in this study were similar to in literature data (AKSOY, 1995; ISGUZAR and TESTIK, 1999). These values average carcass weights were similar to Bronze turkeys having 4794.0 to $3965.5 \mathrm{~g}$ at 18 weeks (ISGUZAR and TESTIK, 1999), and higher to Bronze turkeys having 4324.5 to $2695.5 \mathrm{~g}$ at 18 weeks (SARICA et al., 1991b) and to Bronze turkeys having 3348.3 to $3064.2 \mathrm{~g}$ at 16 weeks (ŞENGUL, 2001), and lower to Bronze turkey having 8860 to $6190 \mathrm{~g}$ and to White turkeys having 9360 to $5740 \mathrm{~g}$ at 25 weeks (MARQUEZ et al., 1983).

In literature data, the average weights of breast, legs, wings, neck, back and edible viscera were 1433.0 to $2370 \mathrm{~g}, 1399.0$ to $2065.0 \mathrm{~g}, 554$ to $736 \mathrm{~g}, 383$ to $989 \mathrm{~g}, 1229$ to $1269 \mathrm{~g}$ and 381 to $303 \mathrm{~g}$ of Bronze turkeys at 18 weeks of age, respectively (ISGUZAR and TESTIK, 1999), and 4520 to $2815 \mathrm{~g}$ for (breast+back), 2085 to $1311 \mathrm{~g}$ for legs, 886.5 to $609 \mathrm{~g}$ for neck, 384.5 to $286.0 \mathrm{~g}$ for back and 424.0 to $287.5 \mathrm{~g}$ for edible viscera of Bronze turkeys at 24 weeks of age (AKSOY, 1995).

\section{Nutrient content of meat}

The studies related to this subjects in literature data that the average percentages of crude protein and fat were reported by researches of turkeys. These values were 24.5 $\%$ for the average percentages of crude protein in breast muscle meat and $20.5 \%$ in legs muscle meat, and $1.3 \%$ for crude fat in breast muscle meat and $4.2 \%$ in legs muscle meat of Large Breasted Bronze turkeys (KOCAK, 1984); 23.1 to $24.1 \%$ for the average percentages of crude protein in the breast muscle meat of males-females and 19.9 to $19.8 \%$ in legs muscle meat; 3.8 to $4.2 \%$ in breast muscle meat and 4.3 to $4.0 \%$ in legs muscle meat for crude fat of Bronze turkeys at 28 weeks, respectively (ISGUZAR and TESTIK, 2001); 21.0 to $25.0 \%$ for crude protein and 2.6 to $11.0 \%$ for crude fat in muscle meat of Bronze turkeys (TUNCER, 2001). For the comparison of our data with literature, the results were similar to (KOCAK, 1984; ISGUZAR and TESTIK, 2001; TUNCER, 2001;) of Bronze turkeys for crude protein content in breast and legs muscle meat, but, lower in breast muscle meat of Bronze and White turkeys and in legs muscle meat of White turkeys for crude fat contents. Average percentages of crude protein and crude fat content values in White turkeys were lower than the literature data. This differences had due to different genotypes and feeding.

\section{Feed consume}

In the literature, Beltsville White and Broad Breasted White turkeys had measured food conversion as 2.3 and 2.5 at $12 \mathrm{wk}$, and with 2.9 and 3.0 at $16 \mathrm{wk}$, respectively (GANSEL and NEUBAUER, 1974). Feed intake of turkeys was $2.97-3.58 \mathrm{~kg} / \mathrm{kg}$ body weight and highest profit was obtained by slaughtering at 14 weeks old (KUCKA, 1989), and daily food consumption for turkeys averaged 10.2 to $10.7 \mathrm{~g}$ at first 2 weeks; 32.5 to $33.7 \mathrm{~g}$ over the $12 \mathrm{wk}$ period and food conversion for turkeys ( $\mathrm{g}$ food $/ \mathrm{g}$ gain) 3.00 to 2.89 over the 12-wk period (JAGBIR SINGH et al., 1991), and with consumption varying from 2.77 to $4.38 \mathrm{~kg} / \mathrm{kg}$ weight gain for turkey (KUCKA, 1991). 
In the study, the values of average feed intake and food conversion ratios were similar to those in the literature.

\section{Conclusion}

With this study, it was determined that growth, carcass composition and nutrient content of meat of Bronze and White turkeys in comparison at 14 and 18 weeks of age. We saw that White turkeys were very fast growing genotypes and they produced turkey meat much more than Bronze turkeys in the same period. In this way, to increase of turkey meat production under the intensive conditions, there is a need to the fast growing turkey genotypes and to similar hybrid genotypes in Turkey. In this study, White turkeys had seemed to have advantages according to Bronze turkeys for much more turkey meat production in short time.

\section{References}

AKSOY, T.; ISCAN, N.:

A technical investigation on nutrition by to put out to graze of Bronze turkeys in Tekirdağ province in Turkey. International Poultry Fair and Congress-95: 97-107, Istanbul/Turkey, 1995

AKSOY, T.:

The slaughter results of Bronze turkey's nourishing in the farm conditions in Tekirdağ province /Turkey. I th National Zootechnical Science Congress: 48-54, Antalya/Turkey, 1996

ANON:

Analyzis methods of food stuffs (book). The Ministry of Agriculture and Forest press, Ankara/Turkey, 1993

ARABA, A.A.; MIRELES, JR.:

High Oil Corn: an evaluation of its nutritional value in BUTA tom and hen turkeys. (Unpublished data.), Poultry Research Trial - AFG6063, California, 1993

BRANT, A.W.:

A brief history of the turkey. World's Poultry Science Journal, 54 (1998), 365-373

CELEN, F.; TESTIK, A.:

A study on effects to turkey performance of light and equipment colours. International Fair and Poultry Congress-95: 117-125, Istanbul/Turkey, 1995

FERKET, P.R.; SELL, J.L.:

Effect of severity early protein restriction on Large turkey toms. 2. carcass characteristics. Poultry .Sci. 68 (1989), 687-697

GANSEL, K.; NEUBAUER, H.:

Present developments in breeding, reproduction and production of turkeys and further problems in the period up to 1980. Tierzucht, 28: 6, 275-277, Rec. 1 of 152-CAB Abst.(1972-1975), 1974

GILLIS, WA.; ORR, HL.; USBORNE, WR.:

Ultrasonic estimation of carcass yield in turkey broilers. Poultry Sci. 22 (1973), 421-424

ISGUZAR, E.; TESTIK, A.:

An investigation on growth, carcass characteristics and meat quality of Bronze turkeys with every day herding in extansive conditions as primitive in Turkey. GAP II Agricultural Congress, 2: 1125-1131, Sanliurfa/Turkey, 2001

JAGBIR SINGH, C.K.; AGGARWAL, C.K.; CHOPRA, S.K.:

Effect of incandescent vs infra-red lamp brooding on the performance of turkey poults. Indian Journal of Animal Production and Management 1991, 7: 3, 166-168; 4 ref., Rec. 144 of 208-CAB Abst. 19901991

JAMES, CS.:

Analytical chemistry of foods. Chapmon \& Hall, First edition, 1995

KOCAK, C:

Turkey husbandry. The Ministry of Agriculture and Forest press 48, Ankara/ Turkey, 1984

KUCKA, E.:

Trends of costs and size of profit in relation to age of turkey at co-operative breeding farms.

Oeconomica 1989, N. 23: 31-40; 4 ref., Rec. 146 of 208-CAB Abst. 1990-1991

KUCKA, E.: 
A study of the efficiency of breeding and rearing turkeys. Oeconomica 1991, N. 26, Supplementum A, 54pp.; 12 tab., 2 fig.; 112 ref., Rec. 170 of 208-CAB Abst. 1993-1994

LESSON, S.; SUMMERS, J.D.:

Commercial Poultry Nutrition (second edition). Book, ISBN 0-9695600-2-8, Depart. of Animal \& Poultry Science, University of Guelph, Guelp, Ontario, Canada, p:310-311, 1997

MARQUEZ, OV.; OCHOA, GP.; BARRANCO, CJ.; ROMANO, PJJ. :

Carcass characters in two types of turkey reared in two environments. Veterinaria, Mexico 14: 2, 63-68;

MEİJERHOF, R.:

Turkeys grow better with intermittent light. Misset-world Poultry, vol.7, no. 1, 1991

MORAN, E.T.; ORR, H.L.; LARMOND, E.:

Production efficiency, grades and yields with the Large White Turkey as related to sex and age. Poultry NIXEY, C.: Sci. 49 (1970), 475-493

A comparison of growth and fat deposition of commercial avian species. $7^{\text {th }}$ European Poultry Conference, Paris: 24-28, 1986

POPESCU VIFOR, S.; PUSCATU, I.:

Genetic parameters of some external characters in turkey broilers. D Zootehnie (1977-1978), publ. 1979, 20-21: 75-80; 6 ref., Rec 57 of 263-CAB Abst.(1979-1981), 1979

SALMON, R.E.:

Effect of dietary fat concentration and energy to protein ratio on the performance, yield of carcass components and composition of skin and meat of turkeys as related to age. British Poult. Sci. 15 (1974), 543-560

SALMON, R.E.:

Slaughter losses and carcass composition of the medium White turkey. British Poult. Sci. 20 (1979), 297-302

SARICA, M.; SAYLAM, S.K.; OZTURK, E.:

A study on performance and the determination of the most proper slaughter age of turkeys in the semiintensive conditions in Turkey. The Research Institute of Poultry journal, 71: 15-20, Ankara/Turkey, 1991a

SARICA, M.; SAYLAM, S.K.; OZTURK, E.:

Effects on carcass traits of Bronze turkeys of slaughter age and sex in the semi-intensive conditions in Turkey. International Poultry Congress-91, 92-103, Istanbul/Turkey, 1991b

SENGUL, T.:

Season effects on performance traits and carcass yields of Bronze turkeys. Ciftlik periodical journal, p: 75-80, Turkey, 2001

TESTIK, A.; CELEN, F.:

An investigation on the some native and forein turkey genotypes performance. International Poultry Congress-93: 211-216, İstanbul/Turkey, 1993

TUNCER, I.:

Turkey husbandry. Ciftlik periodical, p: 24-25, Turkey, 2001

TURKOGLU, M.; AKBAY, R.; KOCAK, C.; ELEROGLU, H.:

New approaches on turkey breeding in Turkey. International Poultry Congress-90: 296-302, Istanbul/Turkey, 1990

TURKOGLU, M.; AKBAY, R.; KOCAK, C.; ELEROGLU, H.:

A New approach for turkey breeding in Turkey. International Poultry Congress-91: 52-58, Istanbul/Turkey, 1991

WISCHHUSEN, L.:

The Turkey Market. CAB Abst.1976-78, Record 34 of 208, 1975

Received: 2002-11-29

Accepted: 2003-08-14

Author's address

Dr. ERGÜL İŞGÜZAR

Süleyman Demirel University,

Faculty of Agriculture,

Depart. of Animal Breeding,

Isparta-Turkey 